\title{
The seminal role played by Pierre Marie in Neurology and Internal Medicine
}

\author{
0 papel essencial de Pierre Marie na neurologia e na medicina interna \\ Gustavo M. de Almeida, Francisco M. B. Germiniani, Hélio A. G. Teive
}

\begin{abstract}
The authors review the most important contributions of Pierre Marie to the elucidation and description of several neurological diseases, such as Charcot-Marie-Tooth's disease and hereditary cerebellar ataxia, as well as his contributions to Internal Medicine, including his pioneering studies on acromegaly, ankylosing spondylitis, and hypertrophic pulmonary osteoarthropathy. His works led to incontestable advances in the medical sciences that transcended his time.
\end{abstract}

Keywords: history of neurology, Charcot-Marie disease, hereditary cerebellar ataxia, acromegaly, ankylosing spondylitis.

\section{RESUMO}

Os autores revisaram as mais importantes contribuições de Pierre Marie para a elucidação e a descrição de várias doenças neurológicas, tais como a doença de Charcot-Marie-Tooth e a ataxia cerebelar hereditária, bem como na medicina interna, incluindo os seus estudos pioneiros na acromegalia, espondilite anquilosante e osteo-artropatia hipertrófica pulmonar. Os seus trabalhos promoveram uma crescimento incontestável das ciências médicas que transcenderam o seu tempo.

Palavras-chave: história da neurologia, doença de Charcot-Marie, ataxia cerebelar hereditária, acromegalia, espondilite anquilosante.

During the $19^{\text {th }}$ and $20^{\text {th }}$ centuries clinicians, anatomists and pathologists carried out extensive work in the field of Neurology. Special credit should be given to Pierre Marie, an eminent French neurologist of the late nineteenth century and early twentieth century. ${ }^{1,2,3}$ Marie was the most devoted of Charcot's students, and worked together with his mentor at the Salpêtrière hospital for fifteen years (1878 to 1893) $)^{1,2}$. After Charcot's death, Marie worked at the Bicêtre Hospital (1893-1918) and only returned to the Salpêtrière in 1918, to take up Charcot's vacant place as the head of the Discipline of Neurology ${ }^{1,2,3}$. The purpose of this paper is to highlight the role played by Marie in the advancement of Neurology and also his important contributions to Internal Medicine.

\section{BIOGRAPHICAL DATA}

Pierre Marie (Figure) was born in Paris, France, on September 9, 1853, and died on April 13, 1940, at the age of 87 in Le Pradet near Cannes, France ${ }^{1,2,3}$. He was a prominent member of the French neurological world of the late nineteenth and early twentieth centuries and a brilliant student under Charcot ${ }^{1,2,3}$. At the end of his residency he defended his MD thesis on Basedow-Graves' disease and became chief resident under the direction of Charcot, as well as chef de clinique and chefde laboratoire ${ }^{1,2,3}$. He then worked with Charcot in his private office as a personal assistant. In 1878 he was appointed interne des Hôpitaux de Paris, in 1889 associate professor at the Paris Medical School and in 1897 associate professor and head of Neurology at the Bicêtre hospital ${ }^{1,3}$. He was appointed professor of Pathology in 1907, and later became a member of the Académie Nationale de Médecine. Together with Édouard Brissaud, he founded the journal Revue Neurologique in 1893, and the Société de Neurologie de Paris, of which he was the first general secretary, in $1899^{1,3}$. In 1918, at the age of 64, after the death of Dejerine - whom he hated most implacably - he was appointed to take up Charcot's vacant place as the head of the Discipline of Neurology in the Clinique des Maladies du Système Nerveux at the Salpetrière, which he held for eight years, from 1918 until his retirement in 1925. ${ }^{1,2,3}$ Marie's work always reflected his scientific skills and was performed with rigor and exactness. 


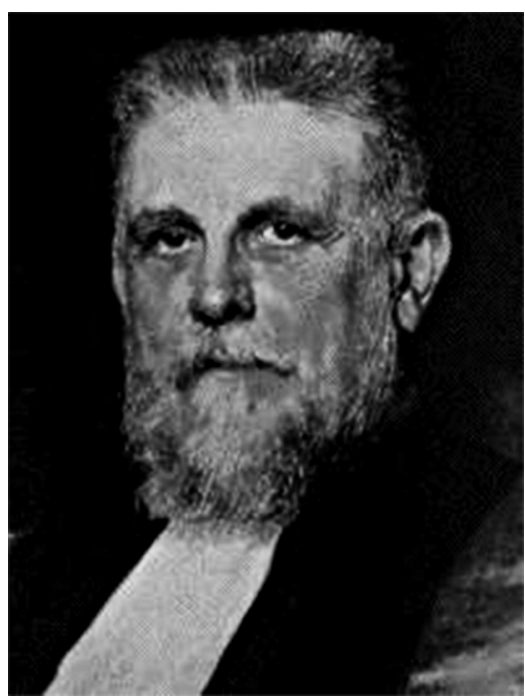

(Taken from Google Images: www.ms.gateway.gen.tr)

Figure. Pierre Marie (1853-1940).

\section{MARIE'S CONTRIBUTIONS TO NEUROLOGY}

Marie was an outstanding neurologist and published several important neurological studies during his career that eventually became classics. These included the classical description of a hereditary motor and sensory neuropathy known as Charcot-Marie-Tooth's (CMT) disease, considered one of the most common hereditary neurological diseases ${ }^{1,3}$. Charcot and Marie originally published a paper in 1886 about a familial neuropathy with progressive muscular atrophy under the title Sur une forme particulière d'atrophie musculaire progressive souvent familiale débutant par les pieds et les jambes et atteignant plus tard les mains ${ }^{4}$. Another important contribution by Marie to Neurology was the description of hereditary cerebellar ataxia in 1893 known as Marie's atax$\mathrm{ia}^{1,2,3,5}$. This form of hereditary cerebellar ataxia was clinically distinct from that described by Friedreich and was characterized by adult onset, abnormal eye movements, increased tendon reflexes, marked atrophy of the cerebellum and an autosomal dominant inheritance ${ }^{1,2,3,5}$. An important achievement by Marie related to ataxia was the definition of a form of sporadic idiopathic cerebellar ataxia with late onset known as Marie-Foix-Alajouanine's disease in the paper De l'atrophie cérébelleuse tardive à predominance corticale ${ }^{6}$. His views on aphasia were opposed to those of Paul Broca and Karl Wernicke, and this resulted in several famous and intense debates with Dejerine in 1908 at the Société de Neurologie de Paris, which became known around the world as the "Paris aphasia debate" ${ }^{1,3}$. Marie published various works dedicated to the neurological sequelae of World War I injuries in collaboration with Charles Foix and Henry Meige. He also studied hysteria and described cerebellar tonsil herniation and the neurological symptoms complicating smallpox ${ }^{1,2,3}$.

\section{MARIE'S CONTRIBUTIONS TO INTERNAL MEDICINE}

Marie authored several studies in Internal Medicine, particularly Endocrinology, Rheumatology and Orthopedics ${ }^{1,2,3}$. Between 1886 and 1889 he made the first clinical and pathological description of acromegaly, after which the condition became known as Pierre Marie's disease ${ }^{7}$. In 1886 he published a clinical description of two cases of acromegaly observed in Professor Charcot's clinic (he used the term acromegaly for the first time) and, in 1889, a description of its association with pituitary tumors ${ }^{1,3,7}$. In the following years, Marie and his co-workers Marinesco and Souza-Leite (a Brazilian neurologist) published important papers on acromegaly or "maladie de Marie" (1890, 1891), emphasizing important clinical features and pathological findings ${ }^{1,2,3}$. Other contributions by Marie to Endocrinology were his studies of Basedow-Graves' disease and of postural hand tremor in hyperthyroidism ${ }^{1,3}$. In 1890 he published the first description of pulmonary hypertrophic osteoarthropathy, later known as Marie-Bamberger's disease. This disease is frequently associated with lung cancer, when it is known as paraneoplastic hypertrophic osteoarthropathy ${ }^{1,3,8}$. In 1898 Marie described a new syndrome termed cleidocranial dysostosis, a rare disorder with autosomal dominant inheritance characterized by clavicular hypoplasia as well as tooth and craniofacial abnormalities. ${ }^{1,3}$ In the same year, he published a seminal paper entitled Sur la spondylose rhyzomélique, today known as ankylosing spondylitis (AS) ${ }^{1,3,9}$. His clinical description of AS, including young adult onset, a progressive course and spinal stiffness, with kyphosis and ankylosis of the hips, was very comprehensive ${ }^{1,3,9}$. Later, between 1899 and 1906, Marie and his student Léri conducted pathological studies with a group of twelve AS patients ${ }^{10}$. Marie is now considered the pioneer of research into AS, a prototypical inflammatory spondyloarthropathy.

\section{CONCLUSION}

Marie's studies contributed to the elucidation and description of several neurological diseases, such as CMT disease and hereditary cerebellar ataxia. In Internal Medicine, he described an impressive number of diseases, including acromegaly, ankylosing spondylitis and hypertrophic pulmonary osteoarthropathy ${ }^{1,2,3}$. His works led to incontestable advances in the medical sciences that transcended his time. 
1. Goetz CG. Pierre Marie: gifted intellect, poor timing and unchecked emotionality. J Hist Neurosci. 2003;12(2):154-66. doi:10.1076/jhin.12.2.154.15537

2. Broussolle E, Poirier J, Clarac F, Barbara JG. Figures and institutions of the neurological sciences in Paris from 1880 to 1950. Part III: Neurology. Rev Neurol (Paris). 2012;168(4):301-20. doi:10.1016/j.neurol.2011.10.006

3. Paciaroni M, Bogousslavsky J. Jules Joseph Dejerine versus Pierre Marie. In: Bogousslavsky J. Following Charcot: a forgotten history of neurology and psychiatry. Basel: Karger; 2011. p. 162-9.

4. Marie P, Charcot JM. Sur une forme particulière d’atrophie musculaire progressive souvent familiale débutant par les pieds et les jambs et atteignant plus tard les mains. Arch Neurol.1886;6:511-2.

5. Marie P.Sur l'hérédo-ataxie-cérébelleuse. Sem Méd Paris. 1893;13:444-7.

6. Marie P, Foix C, Alajouanine T. De l'atrophie cérébelleuse tardive à predominance corticale. Revue Neurol. 1922;38:850-85,1082-111.

7. Marie P.Sur deux cas d’acromégalie. Revue Med Paris. 1886;6:297-333.

8. Marie P. De l'ostéo-artropathie hypertrophiante pneumique. Rev Med. 1890;10:1-36.

9. Marie P. Deux cas de spondylose rhyzomélique. Bull Mem Soc Méd Hôp Paris. 1898;15:121-5.

10. Marie P, Leri A. La spondylarthrite ankylosante: anatomie, et pathologie. Nouv Icon Salpètrière. 1906;19:32-7. 